\title{
Research on Regional Plant Landscape of Industrial Cities in Henan Province
}

\author{
Zhiyuan Xie ${ }^{l}$, Ying Huang ${ }^{1 *}$, Xinghua $H u^{2}$ \\ ${ }^{1}$ School of Tourism and Landscape Architecture, Guilin University of Technology, 541006 Guilin, Guangxi, China \\ ${ }^{2}$ Guangxi Institute of Botany, Chinese Academy of Sciences, 541006 Guilin, Guangxi, China
}

\begin{abstract}
Plant landscape is an indispensable part of the city. Regional plant landscape not only has excellent ecological benefits, but also can better show the regional characteristics and human culture of the city. Through the analysis of plant landscape in the industrial city, it is concluded that how to make better use of plants to create urban plant landscape with regional characteristics is the focus of regional plant landscape construction.
\end{abstract}

\section{Introduction}

With the rapid development of China's economy, the process of urbanization and industrialization has also been significantly accelerated. In the early stages of urban industrial development, the backwardness of industrial technology and the unreasonable development of resources caused serious environmental pollution. With the advancement of science and technology, the optimization and upgrading of the industrial structure, coupled with the increase of people's awareness of environmental protection, and increased efforts to control pollution, the air quality in industrial cities has gradually improved. This is the epitome of most industrial cities in China. The industrial cities in Henan Province mainly include Zhengzhou, Jiaozuo, and Pingdingshan etc. As an industrial city, economic development is closely related to environmental quality. Although mining mineral resources promotes economic development, it also brings many environmental pollution problems, such as air pollution and soil pollution. As we all know, plants have the function of purifying the air and protecting the environment. In the process of applying plants to create landscapes and improve the environment, industrial cities have also formed distinctive regional plant landscapes. Therefore, this research takes the industrial cities in Henan as the research object, and studies the regional plant landscapes of each city, in order to provide a reference for greening and beautifying the city.

\section{The role of plant landscape in environmental protection}

\subsection{Purification and noise reduction effects of plants on the city}

The impact of plants on the air is mainly reflected in the fact that plants can absorb harmful gases, purify the air, and can also reduce noise and adjust the climate. Some plants are highly resistant to air pollution, and can also absorb and accumulate pollutants [1], thereby purifying the air and protecting the environment. For example, Nerium oleander, Sophora japonica, Cinnamomum camphora, Privet, Koelreuteria paniculata, Ginkgo, Willow, Platanus, Crape myrtle, Ailanthus altissima, Paper mulberry, Chinese rose and other tree species have high resistance to $\mathrm{SO}_{2}$. They can be produced by absorbing and using $\mathrm{SO}_{2}$, and Sulfate becomes a substance beneficial to plant growth. These plants usually have dense leaves, leathery leaves or waxy layers and fluff, the harmful gas is difficult to pass through [2], which can be used as the basis to select suitable anti-pollution plants for industrial cities. The high and low scattered and rich plant landscape can not only beautify the environment, but also more effectively to purify the air and reduce the noise.

\subsection{Purification effect of plants on soil pollution}

Plants can absorb, utilize and enrich some heavy metal elements in the soil. For example, Holly, Poplar and other tree species have a high enrichment capacity for heavy metal elements such as $\mathrm{Cr}, \mathrm{Zn}, \mathrm{Cu}, \mathrm{Pb}$ in the soil, which can transfer the heavy metals in the soil to the aboveground parts of plants [3]. Through the centralized treatment of plant above-ground parts, it can effectively reduce soil pollution and improve soil fertility [4].

\section{General situations of plants in the industrial cities of Henan Province}

Henan has a long history, which has witnessed the various stages of China's historical development. As the political 
and Cultural Center for most of China's history, Henan developed many industries in ancient times and retained many ancient industrial heritages. In modern history, modern industrial cities were also born in Henan Province, such as Luoyang, Zhengzhou, and Jiaozuo [5]. Although the rise of industry has led to the rapid development of economy, but also caused urban environmental pollution, and the air pollution has become the main problem of the urban environment. In the past five to ten years, "smog" has appeared in many cities in Henan Province, and the air quality of each city in Henan Province is far behind that of other cities. In recent years, through the national policy guidance and significant efforts of governance, air quality has been significantly improved, but it has brought various aspects of impact, plant landscape is one of them. In order to create urban landscape and reduce air pollution, some anti-pollution tree species have been applied in some cities, forming a special regional plant landscape.

Henan Province is in the central plains, belonging to the transition from subtropical to warm temperate continental monsoon climate, have four distinct seasons, and enough rainfall. Henan Province is rich in plant resources, most of northern and southern plants are grow well here. The native plants in Henan mainly include Poplar, Ailanthus altissima, Sophora japonica, Willow, Paulownia, Melia azedarach, etc. [6]. The representative plants of main industrial cities in Henan Province are shown in Table 1.

Table 1. A survey of representative plants in major industrial cities of Henan Province

\begin{tabular}{|c|c|c|c|}
\hline $\begin{array}{l}\text { Serial } \\
\text { number }\end{array}$ & $\begin{array}{l}\text { Major industrial } \\
\text { cities }\end{array}$ & Main industry & Representative plant \\
\hline 1 & Zhengzhou & $\begin{array}{l}\text { Aluminum, steel, automobile } \\
\text { manufacturing, cement, } \\
\text { cigarettes, etc. }\end{array}$ & $\begin{array}{l}\text { Platanus, Rosa chinensis, Chinese } \\
\text { scholartree, Paulownia purpurea, } \\
\text { Populus tomentosa }\end{array}$ \\
\hline 2 & Luoyang & $\begin{array}{l}\text { Non-ferrous metal smelting, } \\
\text { fuel processing industry, } \\
\text { equipment manufacturing } \\
\text { industry, etc. }\end{array}$ & $\begin{array}{l}\text { Peony, Ginkgo biloba, Gleditsia } \\
\text { sinensis } \\
\text { Honeysuckle, Elm }\end{array}$ \\
\hline 3 & Jiaozuo & $\begin{array}{l}\text { Chemical industry, equipment } \\
\text { manufacturing, light textile } \\
\text { industry, metallurgical } \\
\text { building materials industry, } \\
\text { etc. }\end{array}$ & $\begin{array}{l}\text { Chinese scholartree, Rosa } \\
\text { chinensis, Taxus chinensis, } \\
\text { Eucommia, Qing tan }\end{array}$ \\
\hline 4 & Anyang & $\begin{array}{l}\text { Metallurgical building } \\
\text { materials industry, equipment } \\
\text { manufacturing industry, coal } \\
\text { chemical industry, food and } \\
\text { medicine, etc. }\end{array}$ & $\begin{array}{l}\text { Chinese scholartree, Crape myrtle, } \\
\text { beech, Qing tan, Chou tan, An gui }\end{array}$ \\
\hline 5 & Pingdingshan & $\begin{array}{l}\text { Coal mining and washing } \\
\text { industry, chemical industry, } \\
\text { fuel processing industry, etc. }\end{array}$ & $\begin{array}{l}\text { Camphor, Rosa chinensis, } \\
\text { Paulownia, Cephalotaxus sinensis, } \\
\text { Shan tong zi }\end{array}$ \\
\hline 6 & Luohe & $\begin{array}{l}\text { Food industry, chemical } \\
\text { industry, equipment } \\
\text { manufacturing industry, etc. }\end{array}$ & $\begin{array}{l}\text { Paulownia, Rosa chinensis, Qi liu, } \\
\text { False indigo, Ash trees }\end{array}$ \\
\hline
\end{tabular}

\section{Case study -- Analysis of regional plant landscape in Pingdingshan}

\subsection{Overview of Pingdingshan}

\subsubsection{Natural conditions in Pingdingshan}

Pingdingshan is in the central-southern part of Henan Province, between $33^{\circ} 08^{\prime}-34^{\circ} 20^{\prime}$ north latitude and $112^{\circ} 14^{\prime}-113^{\circ} 45^{\prime}$ east longitude. It is in the transitional zone between mountains and plains, and has the characteristics of high west and low east. Pingdingshan has a continental monsoon climate, located on the edge of a warm temperate zone and a subtropical climate, with four distinct seasons and enough sunlight and rainfall. The city's annual average total sunshine hours are about 1868-
$2378 \mathrm{~h}$, and the annual average temperature is between $14.8 \sim 15.2^{\circ} \mathrm{C}$; the extreme minimum temperature is $11.3^{\circ} \mathrm{C}$, and the extreme maximum temperature is $38.1^{\circ} \mathrm{C}$. The average annual precipitation in the city is about $1000 \mathrm{~mm}$, which is suitable for the growth of most woody plants.

\subsubsection{Social factors in Pingdingshan}

Pingdingshan's industries mainly include coal mining and washing industry, chemical industry, and fuel processing industry. Relying on abundant mineral resources and a solid industrial foundation, Pingdingshan's economic development is very rapid. Although the energy model based on coal mining has driven rapid economic growth, it has also brought serious environmental pollution and climate change. The main pollution includes: when 
mining coal mines, heavy metal elements in coal gangue such as $\mathrm{Cr}, \mathrm{Hg}, \mathrm{Pb}, \mathrm{Cu}, \mathrm{Zn}$, etc. enter the soil and cause soil pollution [7], air pollution caused by coal fly ash, automobile exhaust, sulfur oxide and dust in the atmosphere [8]. Besides, with the growth of the population of Pingdingshan, the demand for resources is also increasing, which leads to the exploitation of more resources. Whether it is human life activities or mining activities, it will inevitably emit a large amount of Carbon causes the continuous increase of carbon emissions, which in turn affects the environment and climate [9]. In the past few years, residents lived in an environment with poor air quality most of the time. Because of this, Pingdingshan's plants are mostly anti-pollution tree species, such as Cinnamomum camphora, Sophora japonica, Koelreuteria paniculata, Privet, etc. The plant landscape is also mainly composed of anti-pollution plants.

\subsection{Analysis of Regional Plant Landscape in Pingdingshan}

\subsubsection{Native plants in Pingdingshan}

Cinnamomum camphora is the city tree in Pingdingshan. Cinnamomum camphora has been planted in Pingdingshan since the 1990s. It has a long history of cultivation and a large scale of planting area. Cinnamomum camphora is a large evergreen tree and a subtropical evergreen broad-leaved tree. It is evergreen all the year round with luxuriant branches and leaves, and it is an excellent tree species as a shade tree, street tree and sound insulation forest. At the same time, Cinnamomum camphora is an important environmental protection tree species because of its resistance to $\mathrm{Cl}_{2}$ and other toxic gases.

The regionality of plant image creates regional plant landscape. Due to the different natural conditions, there are rich and diverse native plants in various places. Native tree species are incomparable in adaptability, stress resistance and cost. The native plants in Pingdingshan include Torreya grandis, Elm, Paulownia, Rhamnus, Sapindus, Shan tong zi, Lian xiang, etc. The common evergreen trees are Cinnamomum camphora, Magnolia grandiflora, Arborvitae, Sabina chinensis, Cedar, Pinus tabulaeformis, Osmanthus, Privet etc.; And the common deciduous trees are Purple-leaf plum, Koelreuteria paniculata, Ginkgo, Ailanthus altissima, Chinese tallow, Melia azedarach, Sophora japonica, Albizia, Acer truncatum, Paper mulberry, Paulownia, Cotinus coggygria etc.

\subsubsection{Regional plant landscape of Pingdingshan}

Through the analysis of the common garden plants in Pingdingshan, the common garden plants in Pingdingshan are shown in Table 2. It can be concluded that in the industrial city, the plants with strong anti-pollution ability are mostly selected. For example, Cinnamomum camphora, Privet, Platanus, Koelreuteria paniculata, Magnolia grandiflora, and Zelkova schneideriana, etc., are mainly used as street trees; In the industrial zone, Sophora japonica, Melia azedarach, Ailanthus altissima, Ash tree, Paper mulberry. These plants either have strong noise reduction, smoke and dust resistance, or have a strong resistance to toxic gases. They have a strong adsorption and purification effect on industrial waste gas, and they can not only beautify the environment, but also purify the air and degrade the heavy metal pollution in the soil. In parks and residential areas, ornamental plants choose Ginkgo, Purple leaf plum, Albizia, Acer monoes, Acer palmatum, Chinese Tallow and Osmanthus, these plants not only have the characteristics of strong adaptability and strong resistance, but also have beautiful tree shape and hue changes; The plants in the waterfronts not only consider the landscape effect, but also consider the purification of water quality. For example, Reed can degrade the biological metabolism; Lotus can also reduce the content of phosphorus and nitrogen in the water, and increase the content of dissolved oxygen in the water.

\section{Conclusion}

The regional plant landscape not only has better ecological benefits, but also better demonstrates the city's regional characteristics and human culture. Through the analysis of the plant landscape in Pingdingshan, Henan Province, the plant landscape of industrial cities has more consideration of the ecological benefits of plants, such as the use of plants to purify air and soil to play an environmental role. At the same time, in the plant landscape construction of Pingdingshan, native plants have not been fully used. During the investigation process, the plant landscape with local characteristics is relatively lacking, with relatively few evergreen plants and colourful leaf plants, and the hue change of the plant landscape is slightly monotonous. There are few applications of plants to reflect urban characteristics. When creating a regional plant landscape, it is not only necessary to "fit the place with trees", but also to reflect the regional characteristics with the plant landscape. How to use plants to better show the urban style is a crucial aspect to be considered in the creation of plant landscapes.

\section{References}

1. Liqiong Z, Xiangdong L, Lijun Z, Shouxian H. Study on the harm of industrial air pollution to eight plants in Nanning J. Guangxi Agricultural Biological Sciences, 4 (2003) : 284-288.

2. Enlai L, Qianqian L. The role of anti-pollution plants in environmental protection J. Modern rural science and technology, 4 (2016): 50

3. Chaojie L. Application of anti-pollution plants in landscaping J. Flowers, (2017): 79-80

4. Danjing Y. Effects of soil organisms on Phytoremediation of heavy metal contaminated soil J. Beijing agriculture, (2014): 275-276

5. Xiao T. Study on landscape reconstruction and reuse of old industrial plant areas in Henan Province J. 
Journal of Nanyang Normal University,11 (2012): 19-22

6. Zhanchao L, Su M, Li W. Current situation and Development Countermeasures of main local tree seedlings in Henan Province J. Henan forestry science and technology, (2018): 38-40

7. Sen Y, Sen Z, Tao L, et al. Evaluation of soil heavy metal pollution in Pingdingshan Coal Mining Area J. Energy and environmental protection, (2019): 51-54
8. Wenbin H. Coal mine air pollution and control countermeasures J. Environment and development, (2017): 64,66

9. Dong P. Discussion on the factors influencing carbon emission exceeding the standard from the development status of Pingdingshan J. Modern commerce, (2012): 135-135

Table 2. Common garden plants in Pingdingshan

\begin{tabular}{|c|c|c|c|c|c|}
\hline $\begin{array}{l}\text { Serial } \\
\text { number }\end{array}$ & Species name & Latin name & Tree species type & $\begin{array}{l}\text { Anti-pollution } \\
\text { effect }\end{array}$ & Application \\
\hline 1 & Cedar & Cedrus deodara & Evergreen tree & $\begin{array}{l}\text { Strong dust and } \\
\text { noise reduction } \\
\text { ability }\end{array}$ & $\begin{array}{l}\text { Parks, streets, } \\
\text { residential } \\
\text { areas }\end{array}$ \\
\hline 2 & $\begin{array}{l}\text { Cinnamomum } \\
\text { camphora }\end{array}$ & $\begin{array}{l}\text { Cinnamomum } \\
\text { camphora }\end{array}$ & Evergreen tree & $\begin{array}{l}\text { Strong } \\
\text { resistance to } \\
\text { harmful gases } \\
\text { such as } \mathrm{Cl}_{2} \text { and } \\
\mathrm{HF}\end{array}$ & $\begin{array}{l}\text { Parks, streets, } \\
\text { industrial } \\
\text { areas }\end{array}$ \\
\hline 3 & Arborvitae & $\begin{array}{l}\text { Platycladus } \\
\text { orientalis }\end{array}$ & Evergreen tree & $\begin{array}{l}\text { Strong } \\
\text { endurance to } \\
\text { dirty air }\end{array}$ & $\begin{array}{l}\text { Parks, streets, } \\
\text { residential } \\
\text { areas }\end{array}$ \\
\hline 4 & Sabina chinensis & $\begin{array}{l}\text { Juniperus } \\
\text { chinensis }\end{array}$ & Evergreen tree & $\begin{array}{l}\text { Beautiful tree } \\
\text { shape, pruning } \\
\text { resistant }\end{array}$ & Parks, streets, \\
\hline 5 & Black pine & Pinus thunbergii & Evergreen tree & $\begin{array}{l}\text { Strong ability to } \\
\text { adapt to the } \\
\text { environment } \\
\text { and protective } \\
\text { effect }\end{array}$ & $\begin{array}{l}\text { Parks, streets, } \\
\text { residential } \\
\text { areas, } \\
\text { industrial } \\
\text { areas }\end{array}$ \\
\hline 6 & $\begin{array}{l}\text { Pinus } \\
\text { tabulaeformis }\end{array}$ & Pinus tabuliformis & Evergreen tree & $\begin{array}{l}\text { Resistance to } \\
\text { barrenness, } \\
\text { strong vitality }\end{array}$ & Parks, streets \\
\hline 7 & $\begin{array}{l}\text { Magnolia } \\
\text { grandiflora }\end{array}$ & $\begin{array}{l}\text { Magnolia } \\
\text { grandiflora }\end{array}$ & Evergreen tree & $\begin{array}{l}\text { Anti-pollution, } \\
\text { anti-wind }\end{array}$ & Parks, streets \\
\hline 8 & $\begin{array}{l}\text { Zelkova } \\
\text { schneideriana }\end{array}$ & Zelkova serrata & Evergreen tree & $\begin{array}{l}\text { Noise reduction } \\
\text { and dust } \\
\text { prevention }\end{array}$ & Parks, streets \\
\hline 9 & $\begin{array}{l}\text { Cherry } \\
\text { blossoms }\end{array}$ & $\begin{array}{l}\text { Cerasus } \times \\
\text { yedoensis }\end{array}$ & Evergreen tree & $\begin{array}{l}\text { Flower tree } \\
\text { species }\end{array}$ & $\begin{array}{l}\text { Parks, } \\
\text { residential } \\
\text { areas }\end{array}$ \\
\hline 10 & Privet & $\begin{array}{l}\text { Ligustrum } \\
\text { lucidum }\end{array}$ & $\begin{array}{l}\text { Evergreen tree or } \\
\text { shrub }\end{array}$ & $\begin{array}{l}\text { Strong } \\
\text { adaptability and } \\
\text { pruning } \\
\text { resistance }\end{array}$ & Parks, streets \\
\hline 11 & Osmanthus & $\begin{array}{l}\text { Osmanthus } \\
\text { fragrans }\end{array}$ & $\begin{array}{l}\text { Evergreen tree or } \\
\text { shrub }\end{array}$ & $\begin{array}{l}\text { It has certain } \\
\text { resistance to } \\
\text { harmful gases } \\
\text { such as } \mathrm{Cl}_{2} \text {, } \\
\mathrm{SO}_{2}, \mathrm{HF} \text { etc. }\end{array}$ & $\begin{array}{l}\text { Parks, } \\
\text { residential } \\
\text { areas, } \\
\text { industrial } \\
\text { areas }\end{array}$ \\
\hline 12 & Loquat & $\begin{array}{l}\text { Eriobotrya } \\
\text { japonica }\end{array}$ & $\begin{array}{l}\text { Evergreen Small } \\
\text { Tree }\end{array}$ & $\begin{array}{l}\text { Beautiful trees, } \\
\text { foliage and fruit } \\
\text { trees }\end{array}$ & $\begin{array}{l}\text { Parks, } \\
\text { residential } \\
\text { areas }\end{array}$ \\
\hline 13 & Platanus & Platanus orientalis & $\begin{array}{l}\text { Large Deciduous } \\
\text { Tree }\end{array}$ & $\begin{array}{l}\text { Strong } \\
\text { adaptability, } \\
\text { strong } \\
\text { resistance to a } \\
\text { variety of toxic }\end{array}$ & $\begin{array}{l}\text { Parks, streets, } \\
\text { industrial } \\
\text { areas }\end{array}$ \\
\hline
\end{tabular}




\begin{tabular}{|c|c|c|c|c|c|}
\hline & & & & gases & \\
\hline 14 & $\begin{array}{l}\text { Sophora } \\
\text { japonica }\end{array}$ & $\begin{array}{l}\text { Styphnolobium } \\
\text { japonicum }\end{array}$ & Deciduous tree & $\begin{array}{l}\text { Strong } \\
\text { resistance to } \\
\text { harmful gases } \\
\text { such as } \mathrm{Cl}_{2} \text { and } \\
\mathrm{SO}_{2}\end{array}$ & $\begin{array}{l}\text { Parks, streets, } \\
\text { residential } \\
\text { areas, } \\
\text { industrial } \\
\text { areas }\end{array}$ \\
\hline 15 & Paulownia & $\begin{array}{l}\text { Paulownia } \\
\text { fortunei }\end{array}$ & Deciduous tree & $\begin{array}{l}\text { Can absorb dust } \\
\text { and smoke, anti- } \\
\text { toxic gas }\end{array}$ & $\begin{array}{l}\text { Parks, streets, } \\
\text { residential } \\
\text { areas, } \\
\text { industrial } \\
\text { areas }\end{array}$ \\
\hline 16 & Apricot & $\begin{array}{l}\text { Armeniaca } \\
\text { vulgaris }\end{array}$ & Deciduous tree & $\begin{array}{l}\text { Flower and fruit } \\
\text { tree species }\end{array}$ & $\begin{array}{l}\text { Parks, } \\
\text { residential } \\
\text { areas }\end{array}$ \\
\hline 17 & Paper mulberry & $\begin{array}{l}\text { Broussonetia } \\
\text { papyrifera }\end{array}$ & Deciduous tree & $\begin{array}{l}\text { Strong } \\
\text { adaptability, } \\
\text { strong } \\
\text { resistance to } \\
\text { harmful gases } \\
\text { such as } \mathrm{Cl}_{2} \text { and } \\
\mathrm{SO}_{2}\end{array}$ & $\begin{array}{l}\text { residential } \\
\text { areas, } \\
\text { industrial } \\
\text { areas }\end{array}$ \\
\hline 18 & Ulmus pumila & Ulmus parvifolia & Deciduous tree & $\begin{array}{l}\text { Strong } \\
\text { resistance }\end{array}$ & $\begin{array}{l}\text { Parks, } \\
\text { residential } \\
\text { areas, } \\
\text { industrial } \\
\text { areas }\end{array}$ \\
\hline 19 & Chinese Tallow & Triadica sebifera & Deciduous tree & $\begin{array}{l}\text { Barren } \\
\text { resistance, } \\
\text { strong } \\
\text { resistance to HF } \\
\text { gas }\end{array}$ & $\begin{array}{l}\text { Parks, streets, } \\
\text { residential } \\
\text { areas, }\end{array}$ \\
\hline 20 & Melia azedarach & Melia azedarach & Deciduous tree & $\begin{array}{l}\text { Resistant to } \\
\text { smoke and dust, } \\
\text { strong against } \\
\mathrm{SO}_{2}\end{array}$ & $\begin{array}{l}\text { Parks, } \\
\text { residential } \\
\text { areas, } \\
\text { industrial } \\
\text { areas }\end{array}$ \\
\hline 21 & $\begin{array}{l}\text { Ailanthus } \\
\text { altissima }\end{array}$ & $\begin{array}{l}\text { Ailanthus } \\
\text { altissima }\end{array}$ & Deciduous tree & $\begin{array}{l}\text { Strong anti- } \\
\text { smoke ability, } \\
\text { extremely } \\
\text { resistant to } \mathrm{Cl}_{2} \text {, } \\
\mathrm{SO}_{2} \text {, nitrogen } \\
\text { dioxide, } \mathrm{HF}\end{array}$ & $\begin{array}{l}\text { Parks, streets, } \\
\text { residential } \\
\text { areas, } \\
\text { industrial } \\
\text { areas }\end{array}$ \\
\hline 22 & Toon & Toona sinensis & Deciduous tree & Cold resistance & $\begin{array}{l}\text { streets, } \\
\text { residential } \\
\text { areas, }\end{array}$ \\
\hline 23 & Hovenia dulcis & Hovenia acerba & Deciduous tree & $\begin{array}{l}\text { Strong } \\
\text { adaptability }\end{array}$ & $\begin{array}{l}\text { Parks, } \\
\text { residential } \\
\text { areas }\end{array}$ \\
\hline 24 & Albizia & Albizia julibrissin & Deciduous tree & $\begin{array}{l}\text { Strong } \\
\text { resistance to } \\
\text { harmful gases } \\
\text { such as } \mathrm{SO}_{2} \text { and } \\
\text { hydrogen } \\
\text { chloride }\end{array}$ & $\begin{array}{l}\text { Parks, streets, } \\
\text { residential } \\
\text { areas, } \\
\text { industrial } \\
\text { areas }\end{array}$ \\
\hline 25 & Ash tree & Fraxinus chinensis & Deciduous tree & $\begin{array}{l}\text { Anti-smoke, } \\
\mathrm{SO}_{2} \text { and } \mathrm{Cl}_{2}\end{array}$ & $\begin{array}{l}\text { Parks, streets, } \\
\text { waterfronts, } \\
\text { residential } \\
\text { areas, } \\
\text { industrial } \\
\text { areas }\end{array}$ \\
\hline 26 & Metasequoia & Metasequoia & Deciduous tree & Some resistance & Parks, streets, \\
\hline
\end{tabular}


glyptostroboides

27

\section{Acer truncatum Acer truncatum}

Acer pictum subsp. mono

29

Bischofia javanica

30

Ginkgo

32
Serissa

\section{Purple Leaf} Plum

Pomegranate

Koelreuteria Paniculata

Koelreuteria paniculata

Pyracantha fortuneana

Serissa japonica 'Variegata'

Buxus japonicus

Prunus cerasifera f. atropurpurea

Punica granatum

Buxus bodinieri
Bischofia
polycarpa

Euonymus maackii

Cotinus coggygria

Lagerstroemia indica

Deciduous tree

Deciduous tree

Deciduous tree

Deciduous tree

Deciduous tree

Deciduous tree

Deciduous tree to $\mathrm{SO}_{2}$

Deciduous tree

Deciduous tree

Deciduous tree

Deciduous tree tree species

resistance to $\mathrm{SO}_{2}$

Extremely resistant to infertility Reduce dust and absorb harmful gases such as $\mathrm{SO}_{2}, \mathrm{Cl}_{2}$ and $\mathrm{HF}$

Adaptable

Flower and fruit

\section{Strong} resistance to dust, $\mathrm{SO}_{2}$ and ozone

Evergreen shrub

Strong absorption and resistance to $\mathrm{SO}_{2}$

Evergreen shrub Evergreen shrub
Foliage tree species

Foliage tree species waterfronts, residential areas, industrial areas Parks, streets, residential areas Parks, streets, residential areas, industrial areas Parks, streets, waterfronts, residential areas, industrial areas Parks, streets, residential areas Parks, streets, residential areas, industrial areas Parks, waterfronts, residential areas Parks, residential areas Parks, streets, waterfronts, residential areas, industrial areas Parks, streets, residential areas Parks, streets, waterfronts, residential areas Parks, streets, residential areas, industrial areas Parks, streets, residential areas, industrial areas Parks, streets, residential areas Parks, streets, residential 


\begin{tabular}{|c|c|c|c|c|c|}
\hline 41 & $\begin{array}{l}\text { Phyllostachys } \\
\text { heterocycla }\end{array}$ & $\begin{array}{l}\text { Nandina } \\
\text { domestica }\end{array}$ & Evergreen shrub & $\begin{array}{l}\text { Adaptable } \\
\text { Foliage and fruit } \\
\text { tree species }\end{array}$ & $\begin{array}{l}\text { areas } \\
\text { Parks, } \\
\text { residential } \\
\text { areas }\end{array}$ \\
\hline 42 & $\begin{array}{l}\text { Jasminum } \\
\text { mesnyi }\end{array}$ & Jasminum mesnyi & Evergreen shrub & $\begin{array}{l}\text { Flower tree } \\
\text { species }\end{array}$ & $\begin{array}{l}\text { Parks, } \\
\text { residential } \\
\text { areas }\end{array}$ \\
\hline 43 & $\begin{array}{l}\text { Nerium } \\
\text { oleander }\end{array}$ & Nerium oleander & $\begin{array}{l}\text { Evergreen erect } \\
\text { large shrub }\end{array}$ & $\begin{array}{l}\text { Strong } \\
\text { resistance to } \\
\mathrm{SO}_{2} \text {, carbon } \\
\text { dioxide, } \mathrm{HF}, \mathrm{Cl}_{2} \\
\text { and other } \\
\text { harmful gases }\end{array}$ & $\begin{array}{l}\text { Parks, streets, } \\
\text { waterfronts, } \\
\text { residential } \\
\text { areas, } \\
\text { industrial } \\
\text { areas }\end{array}$ \\
\hline 44 & $\begin{array}{l}\text { Procumbent } \\
\text { juniper }\end{array}$ & $\begin{array}{l}\text { Juniperus } \\
\text { procumbens }\end{array}$ & $\begin{array}{l}\text { Evergreen creeping } \\
\text { small shrub }\end{array}$ & $\begin{array}{l}\text { Anti-smoke, } \\
\text { anti-SO } \mathrm{SO}_{2} \\
\text { hydrogen } \\
\text { chloride and } \\
\text { other harmful } \\
\text { gases }\end{array}$ & $\begin{array}{l}\text { Parks, streets, } \\
\text { residential } \\
\text { areas, } \\
\text { industrial } \\
\text { areas }\end{array}$ \\
\hline 45 & $\begin{array}{l}\text { Pittosporum } \\
\text { tobira }\end{array}$ & Pittosporum tobira & $\begin{array}{l}\text { Evergreen shrubs or } \\
\text { small trees }\end{array}$ & $\begin{array}{l}\text { Strong } \\
\text { resistance to } \\
\mathrm{SO}_{2}, \mathrm{HF}, \mathrm{Cl}_{2} \\
\text { and other toxic } \\
\text { gases }\end{array}$ & $\begin{array}{l}\text { Parks, streets, } \\
\text { residential } \\
\text { areas, } \\
\text { industrial } \\
\text { areas }\end{array}$ \\
\hline 46 & Fatsia japonica & Fatsia japonica & $\begin{array}{l}\text { Evergreen shrubs or } \\
\text { small trees }\end{array}$ & $\begin{array}{l}\text { Strong } \\
\text { resistance to } \\
\mathrm{SO}_{2}\end{array}$ & $\begin{array}{l}\text { Parks, } \\
\text { residential } \\
\text { areas, } \\
\text { industrial } \\
\text { areas }\end{array}$ \\
\hline 47 & Ilex cornuta & Ilex cornuta & $\begin{array}{l}\text { Evergreen shrubs or } \\
\text { small trees }\end{array}$ & $\begin{array}{l}\text { Tree species for } \\
\text { foliage and } \\
\text { flower viewing }\end{array}$ & $\begin{array}{l}\text { Parks, } \\
\text { residential } \\
\text { areas }\end{array}$ \\
\hline 48 & Photinia frase & Photinia $\times$ fraseri & $\begin{array}{l}\text { Evergreen shrubs or } \\
\text { small trees }\end{array}$ & $\begin{array}{l}\text { Foliage tree } \\
\text { species }\end{array}$ & $\begin{array}{l}\text { Parks, streets, } \\
\text { residential } \\
\text { areas, } \\
\text { industrial } \\
\text { areas }\end{array}$ \\
\hline 49 & $\begin{array}{l}\text { Redrlowered } \\
\text { Loropetalum }\end{array}$ & $\begin{array}{l}\text { Loropetalum } \\
\text { chinense var. } \\
\text { rubrum }\end{array}$ & $\begin{array}{l}\text { Evergreen shrubs or } \\
\text { small trees }\end{array}$ & $\begin{array}{l}\text { Adaptable, } \\
\text { foliage tree } \\
\text { species }\end{array}$ & $\begin{array}{l}\text { Parks, streets, } \\
\text { residential } \\
\text { areas, }\end{array}$ \\
\hline 50 & $\begin{array}{l}\text { Melon seeds } \\
\text { Cyclovirobuxine }\end{array}$ & Buxus sinica & $\begin{array}{l}\text { Evergreen shrubs or } \\
\text { small trees }\end{array}$ & $\begin{array}{l}\text { Foliage tree } \\
\text { species }\end{array}$ & $\begin{array}{l}\text { Parks, streets, } \\
\text { residential } \\
\text { areas, }\end{array}$ \\
\hline 51 & $\begin{array}{l}\text { Ligustrum } \\
\text { quihoui }\end{array}$ & Ligustrum quihoui & $\begin{array}{l}\text { Semi-evergreen } \\
\text { shrub }\end{array}$ & $\begin{array}{l}\text { Resistance to a } \\
\text { variety of toxic } \\
\text { gases }\end{array}$ & $\begin{array}{l}\text { Parks, streets, } \\
\text { residential } \\
\text { areas, } \\
\text { industrial } \\
\text { areas }\end{array}$ \\
\hline 52 & $\begin{array}{l}\text { Forsythia } \\
\text { suspensa }\end{array}$ & Forsythia suspensa & Deciduous shrub & $\begin{array}{l}\text { Strong cold } \\
\text { resistance }\end{array}$ & $\begin{array}{l}\text { Parks, streets, } \\
\text { waterfronts, } \\
\text { residential } \\
\text { areas }\end{array}$ \\
\hline 53 & $\begin{array}{l}\text { Chaenomeles } \\
\text { lagenaria }\end{array}$ & $\begin{array}{l}\text { Chaenomeles } \\
\text { speciosa }\end{array}$ & Deciduous shrub & $\begin{array}{l}\text { Flower tree } \\
\text { species }\end{array}$ & $\begin{array}{l}\text { Parks, } \\
\text { residential } \\
\text { areas, }\end{array}$ \\
\hline 54 & $\begin{array}{l}\text { Berberis } \\
\text { thunbergii }\end{array}$ & $\begin{array}{l}\text { Berberis } \\
\text { thunbergii } \\
\text { 'Atropurpurea' }\end{array}$ & Deciduous shrub & $\begin{array}{l}\text { Adaptable, } \\
\text { foliage tree } \\
\text { species }\end{array}$ & $\begin{array}{l}\text { Parks, streets, } \\
\text { residential } \\
\text { areas, }\end{array}$ \\
\hline 55 & Bauhinia & Cercis chinensis & Deciduous shrub & $\begin{array}{l}\text { Flower tree } \\
\text { species }\end{array}$ & $\begin{array}{l}\text { Parks, } \\
\text { residential } \\
\text { areas }\end{array}$ \\
\hline
\end{tabular}




\begin{tabular}{|c|c|c|c|c|c|}
\hline 56 & False indigo & Amorpha fruticosa & Deciduous shrub & $\begin{array}{l}\text { Strong wind } \\
\text { resistance }\end{array}$ & $\begin{array}{l}\text { Parks, } \\
\text { residential } \\
\text { areas }\end{array}$ \\
\hline 57 & Vitex negundo & Vitex negundo & $\begin{array}{l}\text { Deciduous shrubs } \\
\text { or small trees }\end{array}$ & $\begin{array}{l}\text { Tree species for } \\
\text { foliage and } \\
\text { flower viewing }\end{array}$ & $\begin{array}{l}\text { Parks, streets, } \\
\text { residential } \\
\text { areas, }\end{array}$ \\
\hline 58 & Lilac & Syringa oblata & $\begin{array}{l}\text { Deciduous shrubs } \\
\text { or small trees }\end{array}$ & $\begin{array}{l}\text { Tolerant to } \\
\text { barren, cold and } \\
\text { drought }\end{array}$ & $\begin{array}{l}\text { Parks, streets, } \\
\text { residential } \\
\text { areas, } \\
\text { industrial } \\
\text { areas }\end{array}$ \\
\hline 59 & Chinese rose & Rosa chinensis & Standing shrub & $\begin{array}{l}\text { Cold resistance, } \\
\text { drought } \\
\text { resistance, } \\
\text { strong } \\
\text { resistance to } \\
\text { harmful gases }\end{array}$ & $\begin{array}{l}\text { Parks, streets, } \\
\text { residential } \\
\text { areas, } \\
\text { industrial } \\
\text { areas }\end{array}$ \\
\hline 60 & Japanese spiraea & Spiraea japonica & Standing shrub & $\begin{array}{l}\text { Tolerant to cold, } \\
\text { drought, and } \\
\text { barren }\end{array}$ & $\begin{array}{l}\text { Parks, streets, } \\
\text { waterfronts, } \\
\text { residential } \\
\text { areas }\end{array}$ \\
\hline 61 & Creeping oxalis & Oxalis corniculata & Herb & $\begin{array}{l}\text { Strong } \\
\text { adaptability to } \\
\text { soil }\end{array}$ & Ground cover \\
\hline 62 & Zoysia matrella & Zoysia matrella & Perennial herb & Fine grass & Ground cover \\
\hline 63 & Arab Speedwell & Veronica persica & $\begin{array}{l}\text { Spread multi- } \\
\text { branched herbs }\end{array}$ & Flower plant & Ground cover \\
\hline 64 & Bermudagrass & Cynodon dactylon & Perennial low herb & $\begin{array}{l}\text { Good soil- } \\
\text { retaining plants }\end{array}$ & Ground cover \\
\hline 65 & $\begin{array}{l}\text { Ophiopogon } \\
\text { japonicus }\end{array}$ & $\begin{array}{l}\text { Ophiopogon } \\
\text { japonicus }\end{array}$ & $\begin{array}{l}\text { Perennial evergreen } \\
\text { grass }\end{array}$ & $\begin{array}{l}\text { Cold and } \\
\text { drought tolerant }\end{array}$ & Ground cover \\
\hline 66 & Lotus & Nelumbo nucifera & $\begin{array}{l}\text { Perennial aquatic } \\
\text { herb }\end{array}$ & $\begin{array}{l}\text { Important water } \\
\text { environment } \\
\text { restoration plant }\end{array}$ & $\begin{array}{l}\text { Parks, } \\
\text { waterfronts, } \\
\text { residential } \\
\text { areas }\end{array}$ \\
\hline 67 & Reed & $\begin{array}{l}\text { Phragmites } \\
\text { australis }\end{array}$ & $\begin{array}{l}\text { Tall perennial or } \\
\text { wet grass }\end{array}$ & $\begin{array}{l}\text { Play an } \\
\text { important role } \\
\text { in the } \\
\text { purification of } \\
\text { sewage }\end{array}$ & $\begin{array}{l}\text { Park, } \\
\text { waterfronts }\end{array}$ \\
\hline 68 & Calamus & Acorus calamus & Perennial herb & $\begin{array}{l}\text { Ornamental } \\
\text { plants }\end{array}$ & $\begin{array}{l}\text { Park, } \\
\text { waterfronts }\end{array}$ \\
\hline 69 & Carbungi & Typha angustifolia & $\begin{array}{l}\text { Perennial aquatic or } \\
\text { marsh herb }\end{array}$ & $\begin{array}{l}\text { Good } \\
\text { purification } \\
\text { effect in sewage } \\
\text { treatment }\end{array}$ & $\begin{array}{l}\text { Park, } \\
\text { waterfronts }\end{array}$ \\
\hline 70 & Lotos & $\begin{array}{l}\text { Nymphaea } \\
\text { tetragona }\end{array}$ & $\begin{array}{l}\text { Perennial aquatic } \\
\text { herb }\end{array}$ & $\begin{array}{l}\text { Can absorb } \mathrm{Pb} \text {, } \\
\mathrm{Hg} \text {, phenol and } \\
\text { other toxic } \\
\text { substances in } \\
\text { water }\end{array}$ & $\begin{array}{l}\text { Parks, } \\
\text { waterfronts, } \\
\text { residential } \\
\text { areas }\end{array}$ \\
\hline 71 & Thalia dealbata & Thalia dealbata & $\begin{array}{l}\text { Perennial emergent } \\
\text { herb }\end{array}$ & $\begin{array}{l}\text { Purified water } \\
\text { quality }\end{array}$ & $\begin{array}{l}\text { Parks, } \\
\text { waterfronts, } \\
\text { residential } \\
\text { areas } \\
\end{array}$ \\
\hline
\end{tabular}

